\title{
RAIN-CALL DIALECTS OF THE CHAFFINCH, FRINGILLA COELEBS (FRINGILLIDAE), IN UKRAINE
}

\author{
A. N. Tsvelykh1, E. D. Yablonovska-Grishchenko ${ }^{2}$ \\ ${ }^{1}$ Schmalhausen Institute of Zoology, of the NAS of Ukraine, \\ vul. B. Khmelnytskogo, 15, Kyiv, 01601 Ukraine \\ E-mail:TSV@izan.kiev.ua \\ ${ }^{2}$ Kaniv Nature Reserve, Kaniv, 19000, Ukraine \\ E-mail:aetos@narod.ru
}

Rain-Call Dialects of the Chaffinch, Fringilla coelebs (Fringillidae), in Ukraine. Tsvelykh A. N., Yablonovska-Grishchenko E. D. - Four types of Chaffinch rain-calls were found in Ukraine: "rülsch" - a trill signal widely spread in Europe; "hui" - a whistle signal that occurs in North-Western and Central Europe; "Crimean" whistle signal known only from Crimean peninsula and "Caucasian" signal occurring in Caucasus, Asia Minor and Balkans. Sonograms of rendition versions are given for all of the call types. Distribution of dialects of Chaffinch rain-calls in Ukraine was examined. "Rülsch"- dialect occurs at most of the plane Ukraine and Carpathians. Owing to colonizing artificial afforestations in steppe zone this dialect population's range expanded southward to the coast of the Black and Azov seas. "Hui"-dialect is spread in the Lower Danube region. At the North-Eastern Danube delta Chaffinch's with "hui"- and "rülsch"- rain-calls are found together and a bird was found that uttered both signals alternately but hybrid signals were not registered. It may attest to recent invasion by "rülsch"- population of Chaffinch's there. "Crimean" dialect is distributed in mountainous Crimea and in most of the Crimean steppe zone. "Caucasian" rain-call renditions are registered in cases of individual vagrant birds in eastern Crimea and Lower Danube region.

Key words: Chaffinch, rain-call, sonogram, dialect, Ukraine.

Диалекты дождевого сигнала зяблика, Fringilla coelebs (Fringillidae), в Украине. Цвелых А. Н., Яблоновская-Грищенко Е. Д. - На территории Украины выявлено четыре типа дождевых сигналов зябликов: «rülsch»-сигнал - трелевой сигнал, широко распространенный в Европе, «hui»сигнал - свистовой сигнал, распространенный в Северо-Западной и Центральной Европе, уникальный «крымский» свистовой сигнал, распространённый только на Крымском полуострове, а также «кавказский» свистовой сигнал, распространённый на Кавказе, в Малой Азии и на Балканах. Представлены сонограммы вариантов исполнения сигналов каждого типа. Изучено распространение диалектов дождевых сигналов зябликов на территории Украины. «Rülsch»-диалект распространён на большей части равнинной Украины и в Карпатах. Благодаря заселению искусственных лесонасаждений в степной зоне ареал этой популяции расширился к югу до побережий Чёрного и Азовского морей. «Ниі»-диалект распространён в регионе Нижнего Дуная. В северо-восточной части дельты Дуная зяблики с «hui»- и «rülsch»- дождевыми сигналами встречаются совместно, отмечено попеременное исполнение обоих сигналов одной птицей, но зяблики с гибридными сигналами здесь не выявлены. Это может свидетельствовать о недавнем вселении сюда зябликов «rülsch»-популяции. «Крымский» диалект распространён в Горном Крыму и в большей части степной зоны Крымского полуострова. Исполнение дождевых сигналов кавказского типа зафиксировано у единичных залётных птиц на востоке Крымского полуострова и в Нижнедунайском регионе.

Ключевые слова: зяблик, дождевой сигнал, сонограмма, диалект, Украина.

\section{Introduction}

"Rain-calls" are sequences of rhythmic sounds uttered by Chaffinch males during the nesting period predominantly if they are distressed. Significance of a rain-call is close to that of a song (Tielke, 1976). Different Chaffinch populations may have radically different rain-calls: throughout the vast species range, several highly distinctive rain-call dialects were found (Malchevsky, 1956; Baptista, 1990; Cramp, Perrins, 1994; Tsvelykh, 2003; Tsvelykh, 2011). Such dialects are marks of big geographical populations. At the areas of contact between populations mixed or mosaically distributed dialects can be found (Malchevsky, 1956; 
Tielke 1976; Bergmann et al., 1988; Baptista, 1990; Cramp, Perrins, 1994; Korbut, 1996; Sorjonen, 2001; Tsvelykh, 2003).

This paper aims to discuss the Chaffinch rain-call dialects in Ukraine and to find out the ranges of rain-call populations there.

\section{Material and methods}

Rain-calls of several thousands of birds were listened to in May-June of 2001-2012 in different regions of Ukraine. Rain-calls of 415 birds were recorded with digital video cameras Sony TRV110 E, Sony TRV550 E with remote microphones, and also with digital voice recorders Panasonic US 550RR, Panasonic LS11 with directed zoom microphones. For further analysis the sound files were converted in Wave-format without any clearing or compressing. To process data and obtain sonograms we used Sound Forge 5.0 and Syrinx 5.2s software (Burt, 1995-2005). The sonogram versions of the same signal recorded with different hardware were compared and proven to be identical.

\section{Results and discussion}

Types of Chaffinch rain-calls. There were four rain-call types at the territory of research. Their radical sound difference allowed to definitely identify a rain-call type for each vocalizing bird.

"Rülsch"-signal. This widely spread in Europe rain-call type is represented by rhythmic short rattle trills. We found four rendition versions of that signal (rain-calls sonograms of 375 birds were analysed) in Ukraine. However, these versions (fig. 1, A) are not localized and each of them can be found anywhere at the range of that signal type.

"Hui"-signal. Chaffinch population with unusual whistle rain-calls was found at the Lower Danube region. These signals represented sequences of short melodic whistles, similar in sound to the whistling calls of the Chiffchaff Phylloscopus collybita (Vieill.). This rain-call type is characterized by significant increase in frequency during the sounding (fig. 1, B). Sonograms of these signals (rain-calls sonograms of 8 birds were analysed) were identical to ones of different "hui" signals from Chaffinch populations in North-Western and Central Europe (Baptista, 1990; Sorjonen, 2001). A similar in sound and with same distribution range rain-call type, "huit" signal was not found in the region of research.

"Crimean" signal. Radical differences between whistle rain-calls of Chaffinch subspecies F. c. solomkoi from Crimea and trill "rülsch" signals of ones from Central Europe were first described by H. Kratzig (1943). In the case of Crimean birds this call consists of short melodious whistles which reminds by sounding a whistle call of a Wood Warbler Phylloscopus sibilatrix (Bechst.) (Kratzig, 1943). Rain-calls of the Crimean Chaffinches are unique (fig. 1, C) and they radically differentiate by sounding from other European and Asian Chaffinch populations' rain-call types. The Crimean raincall is characterized (rain-calls sonograms of 31 birds were analysed) by sharply decreasing frequency during the sounding and all together low-frequency renditions maximal frequency of this signal never exceeds $4 \mathrm{kHz}$ (fig. 1, C).

"Caucasian" signal. Rain-calls of Chaffinch subspecies F. c. caucasica from Caucasus and Asia Minor and some of the Balkan region (Tsvelykh, 2011) are very characteristic. These calls are represented by series of loud, high tone sounds, very similar to anxious calls of a Thrush Nightingale Luscinia luscinia (L.) (Tsvelykh, 2003). It differs from other rain-call types. These calls are produced in a frequency range exceeding $4 \mathrm{kHz}$ level and the signal frequency does not really change during sound (fig. 1, $\mathrm{D}, a, b)$.

The nearest to Crimea North-Western edge of Caucasus is inhabited by hybrid population of F. c. caucasica and F. c. solomkoi. Only some of the birds from this region vocalized exclusively by the "Caucasian" type, signals of most of the local Chaffinches include alternating single calls of "Crimean" (fig. 1, C) and "Caucasian" (fig. 1, D, a, 

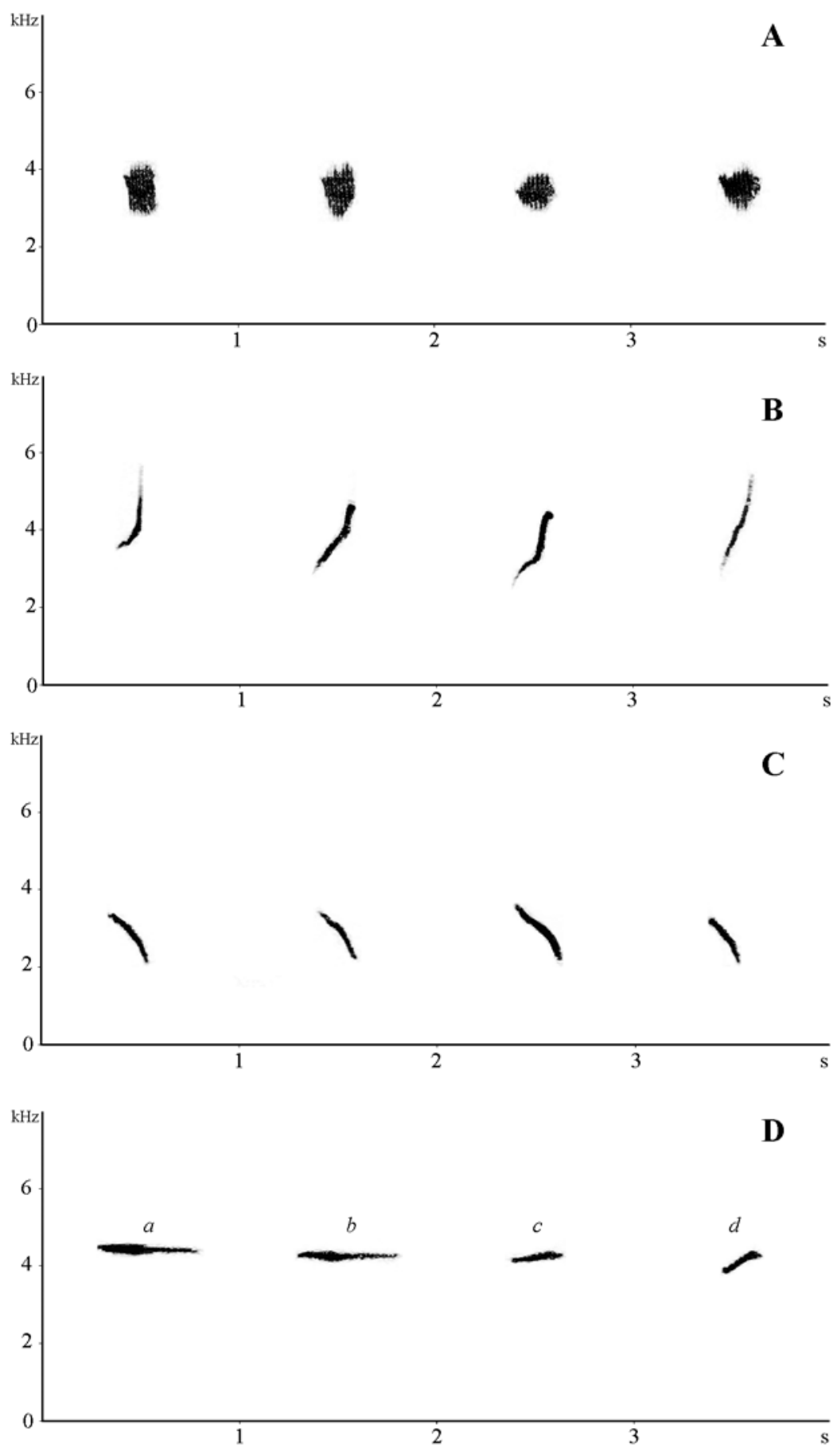

Fig. 1. Rain-call sonograms of Chaffinch from different populations: A - "Rülsch" - rain-calls; B "Hui" - rain-calls; C - "Crimean" rain-calls; D - "Caucasian" rain-calls: $a, b$ - typical "Caucasian" rain-calls (Caucasus, Balkans), $c$ - anomalous shortened "Caucasian" rain-call from the Balkans, $d-$ anomalous rain-call from the Lower Danube region.

Рис. 1. Сонограммы дождевых сигналов зябликов разных популяций: A - «Rülsch»- дождевые сигналы; В - «Нuі»- дождевые сигналы; С - «крымские» дождевые сигналы; D - «кавказские» дождевые сигналы: $a, b$ - типичные «кавказские» дождевые сигналы (Кавказ, Балканы), $c$ - аномальный укороченный «кавказский» дождевой сигнал (Балканы), $d-$ аномальный дождевой сигнал из Нижнедунайского региона. 
b) types (Tsvelykh, 2003). Both of the rendition versions - typical "Caucasian" and "North-Western Caucasian" - were found in Ukraine on Crimean peninsula (see below). Another unusual signal type was recorded only once in the Lower Danube region, in artificial afforestation near Suvorovo village, $20 \mathrm{~km}$ to the North from the Danube river. We tend to view it as an anomalous "Caucasian" rain-call. The sounding of these whistle signals were completely different from the commonly distributed in the Danube region "hui" calls and mostly resembled "Caucasian" rain-calls. Like the "Caucasian" rain-calls they also were uttered mostly at frequency exceeding $4 \mathrm{kHz}$ (fig. 1, D, $d$ ). Unlike typical Caucasian signals (fig. 1, D, $a, b$ ) these calls were shorter and their frequency increased somewhat during sound. We recorded unusual shortened "Caucasian" rain-calls from one Chaffinch male in western Balkans (other local birds uttered typical "Caucasian" rain-calls). These rain-calls (fig. 1, D, c) are structurally quite similar to aforementioned anomalous signals from the Lower Danube region (fig. 1, D, $d$ ). That allows us to suggest that these signals can be grouped with Caucasian type. It is also possible that these anomalous signals are hybrid in origin. For example, hybrid intermediate signals were repeatedly recorded in points of contact between "rülsch" and "hui" rain-call dialects (Baptista, 1990; Korbut, 1996; Sorjonen, 2001). If so, then discussed signals may be a combination of "Caucasian" and "hui"signals because "hui"- call is also quite short and its frequency during sounding also increases, although much faster. We may conclude that these unusual rain-calls at the Lower Danube may be a result of appearance here of an accidental straying bird from the range of southerner "Caucasian" rain-call type, for example from the Balkan region or nearest contact zone of "Caucasian" and "hui"-rain-call populations.

Occurrences of rain-call dialects in Ukraine. Distribution of Chaffinches with different types of rain-calls revealed areas of rain-call dialects in Ukraine (fig. 2).

"Rülsch"-dialect occurs in the forest and forest-steppe zones of Ukraine and in Ukrainian Carpathians. With Chaffinch colonization of artificial afforestations in Ukrainian steppe zone, this dialect has expanded to the northern shore of the Black and Azov seas (fig. 2).

"Hui"-dialect is spread only in the Lower Danube region. Chaffinches with this type of rain-calls inhabit riparian forests here and large artificial afforestations within $20 \mathrm{~km}$ of the river. Only one Chaffinch male with "hui"-calls was registered far away from this region - $250 \mathrm{~km}$ to the north-east from the Danube valley, in the "rülsch"dialect area (fig. 2). This bird was found in artificial afforestation near Berezanka village. It is obvious that, as in the case of the Chaffinch from the Danube region with Caucasian type of rain-call (see below), it was a straying bird that accidentally got out of its population's area.

In the eastern part of the Lower Danube region, directly in the north eastern part of Danube Delta (near Vilkovo town) we found birds with trilling "rülsch" signals alongside the Chaffinches that uttered "hui"-signals that are typical. This situation is characteristic for contact zones between "rülsch" and "hui" rain-call dialects in Central and North-Western Europe. In these contact zones birds with intermediate hybrid versions of signals or birds that utter both signals alternately are not uncommon (Malchevsky 1956, Baptista, 1990; Korbut, 1996; Sorjonen, 2001). We found no birds with intermediate signals in the Lower Danube region. However, in the Danube delta where both signals were recorded, we found one bird that uttered these signals alternately. It is possible that lately birds from "rülsch" population moved into the area, perhaps from the North, where previously only the "hui" population existed.

Chaffinches of the $F$. c. solomkoi subspecies initially inhabited only the Crimean mountains and forested valleys of some Crimean rivers on the plain (Kostin, 1983). Later, the Crimean population range vastly expanded due to the colonization of artificial afforestation on the plains of Crimea. Presently, Crimean rain-call dialect occurs 


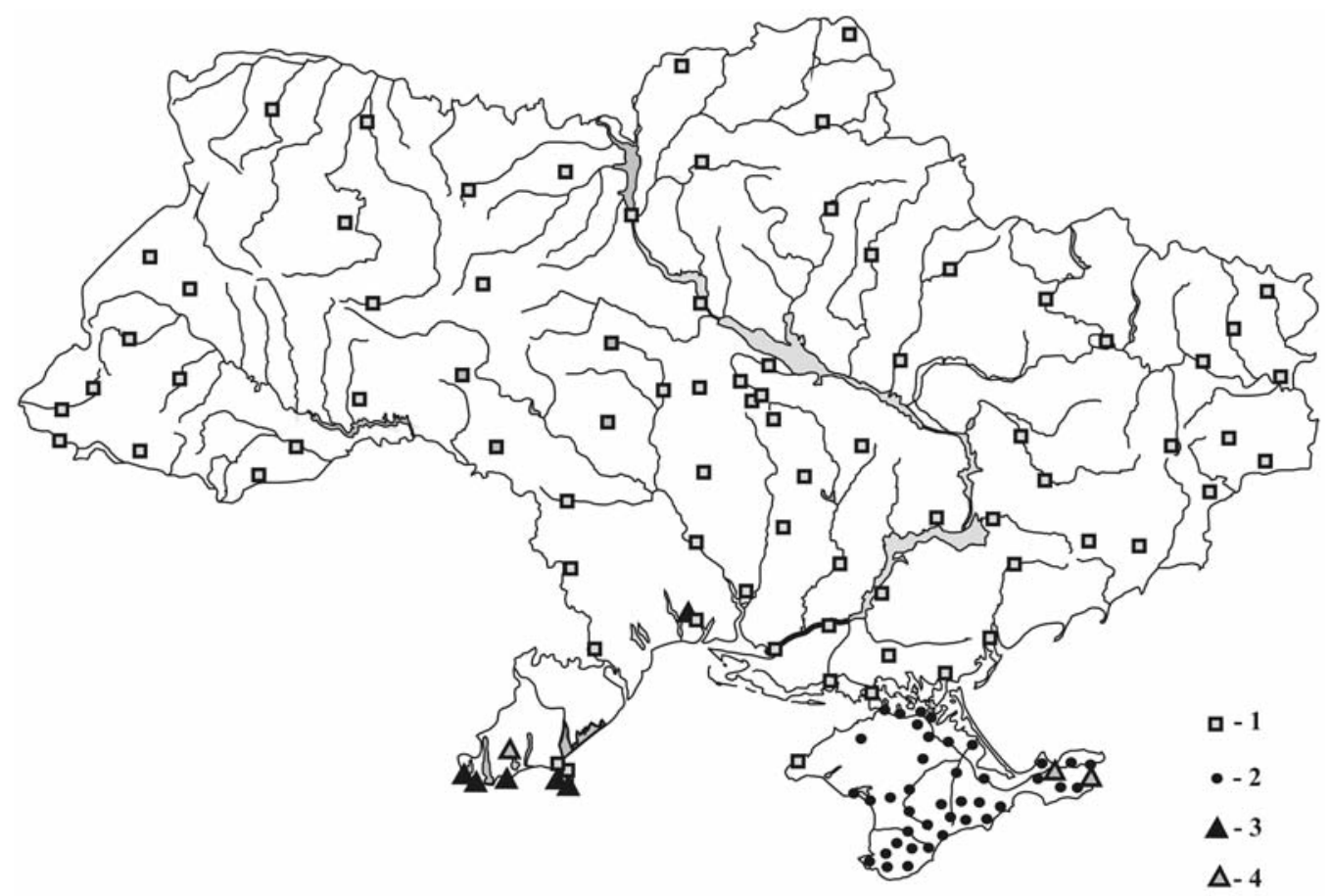

Fig. 2. Occurrences of Chaffinch "rain-call" dialects in Ukraine: 1 - "Rülsch"- dialect; 2 - "Crimean" dialect; 3 - "Hui"- dialect; 4 - "Caucasian" dialect: occurrence of single birds.

Рис. 2. Распространение «дождевых» диалектов зябликов в Украине: 1 - «Rülsch»-диалект; 2 «крымский» диалект; 3 - «Ниі»-диалект; 4 - «кавказский» диалект: встречи одиночных птиц.

on the most of the peninsula except for the North-Western border and at the Crimean isthmus where isolated populations with "rülsch" signals were found (fig. 2). In the southern part of Crimean isthmus, artificial afforestation is colonized by Chaffinches of the "Crimean" population. The distance between "rülsch" and "Crimean" Chaffinch populations does not surpass $15 \mathrm{~km}$ but no rendition of both or hybrid signals was registered in any of them.

Unlike to the previous dialects the "Caucasian" dialect is absent in Ukraine except for occasional stray individual birds with Caucasian rain-call type (fig. 2). Two Chaffinch males with "Caucasian" rain-calls were registered in June, 2004 at the nearest to Caucasus North-Eastern border of Crimean peninsula on the Kerch peninsula (Tsvelykh, 2006). One bird from a forest park near Lenino town vocalized by usual Caucasian type, the second bird from the seaside park of Arshintsevo town uttered the "North-Western Caucasian" version. All other Chaffinches from these and other artificial afforestations of Kerch peninsula vocalized exclusively by the "Crimean" rain-call type. There is no doubt that both "Caucasian" type-vocalizing birds were vagrant from Caucasus. Belonging of unusual rain-call signals of a Chaffinch from the Danube region to the Caucasus dialect was discussed above. It is significant that all of these single birds straying far away from their vocal populations (among them the "Lower Danube" signal type male that was registered far from the region) were found not in the natural habitats but in artificial afforestations where competing for nesting sites is likely easier.

\section{Conclusion}

To summarize, there are four types of Chaffinch rain-call signal on the Ukrainian territory. Among them, the widely distributed in Europe "rülsch" signal; the "hui" sig- 
nal, known from North-Western and Central Europe; the unique "Crimean" signal that is distributed only in the Crimean peninsula and the "Caucasian" signal, distributed in Caucasus, Asia Minor and Balkans. The "rülsch" dialect occurs on most of the plain part of Ukraine and in Carpathians. The "Crimean" dialect occurs in Mountainous Crimea and most of the steppe zone of Crimean peninsula. "Hui" dialect is distributed in the Lower Danube region. This is apparently the most eastern population of the dialect in South-Eastern Europe, because the "hui" signal was previously known only from North-Western and Central Europe. In the North-Eastern part of the Danube delta, Chaffinches that utter "hui" and "rülsch" signals were found together. However there were no birds with hybrid rain-calls. It likely attests to recentness of invasion of "rülsch" vocalizing population into the region. "Caucasian" type of rain-calls is registered in the cases of individual vagrant birds in the eastern part of Crimean peninsula and in the Lower Danube region.

\section{References}

Baptista L. F. Dialectal variation in the rain-call of the Chaffinch (Fringilla coelebs) // Vogelwarte. 1990. - 35. - P. 249-256.

Bergmann H. H., Flottmann E., Heitkamp W. et al. Die Osnabrucker Dialektkarte von Regenrufen des Buchfinken Fringilla coelebs in Jahre 1987 // Vogelkundliche Berichte aus Niedersachsen. — 1988. 20, N 3 - P. 89- 96.

Burt J. 1995-2005. Syrinx, Version 5.2s (http: // www. syrinxpc. com).

Cramp S., Perrins C. M. The birds of the Western Palearctic. - Oxford : University press, 1994. - Vol. 8. $-899 \mathrm{p}$.

Korbut V. V. Geographical distributing and structure of chaffinch (Fringilla coelebs L.) signal "rumenie" on the north-west of Eastern Europe. // Doklady Akademii nauk. - 1996. - 343, N 5. - P. 711-714. Russian : Корбут B. В. Географическое распределение и структура сигнала «рюмение» зяблика (Fringilla coelebs L.) на северо-западе Восточной Европы.

Kratzig H. Der Regenruf des Buchfinken auf der Krim // Ornithologische Monatsberichte. - 1943. - 51. N 3/4. - S. 101.

Malchevsky A. S. Breeding life of songbirds. - Leningrad : Leningrad Univ. Press, 1956. - 281 p. Russian : Мальчевский A. С. Гнездовая жизнь певчих птиц.

Sorjonen J. Long-term constancy of two rain-call dialects of the Chaffinch Fringilla coelebs in Finnish and Russian Karelia: a consequence of site-fidelity? // Ornis Fennica. - 2001. - 78. - P. 73-82.

Thielcke G. A. Bird sounds. - Ann Arbor : Univ. Mich. Press, 1976. - 190 p.

Tsvelykh A. N. Comparative analysis and distribution of the Chaffinch Fringilla coelebs (Aves, Fringillidae) subspecies from the Crimea, Caucasus and Transcaspian region // Zoologichesky zhurnal. - 2003. 82, is. 10. - P. 1250-1257. - Russian : Цвелых A. Н. Сравнительный анализ и распространение подвидов зябликов Fringilla coelebs (Aves, Fringillidae) Крыма, Кавказа и Закаспийского региона.

Tsvelykh A. N. Elements of the Avifauna of the Mountain Crimea in Artificial Isolated Wood Areas of the Kerch Peninsula // Vestnik zoologii. - 2006. - 40, N 3. - P. 241-248. - Russian : Цвелых A. H. Элементы орнитофауны Горного Крыма в островных искусственных лесных массивах Керченского полуострова.

Tsvelykh A. N. What subspecies of Chaffinch Fringilla coelebs Linnaeus, 1758 (Passeriformes: Fringillidae) occurs in South-East Bulgaria? // Acta Zoologica Bulgarica. - 2011. - 63, N 2. - P. 209-211.

Received 18 April 2013

Accepted 20 May 2013 